\title{
THE NON-COOPERATIVE JOURNALISTS' STRUGGLE AGAINST SELF-CENSORSHIP DURING THE NEW ORDER INDONESIA (1967-1998)
}

\author{
Wina Sumiati \\ UIN Sunan Gunung Djati Bandung \\ talovetnaya9@gmail.com
}

\begin{abstract}
In the Soeharto era, the Indonesian journalists were divided into two categories: the cooperative and the non-cooperative ones. Different from the former that obeyed to the government to do self-censorship, the latter category challenged against the government by publishing not only good news, but also any sensitive news about the national problems. In this research, I will analyze the struggle of the non-cooperative journalists, later called the independent journalists, against the regulation of censorship. How they responded to the censorship, and what ways they used to resist the regulation will be the main focuses of the study. In conducting this research, I use history method including heuristic, criticism, interpretation, and historiography. The result of the study shows that the independent journalists took actions by founding an organization called the AJI (the Alliance of Independent Journalists) to organize the journalists with the same goal: ceasing freedom of expression. They also had several alternative media to disseminate the information to avoid the government surveillance, like publishing books, using the internet, conducting seminars, and founding discussion forums with Indonesian students. Their efforts, triggered by the economic collapse factor, succeeded to end the authoritarianism regime.
\end{abstract}

Key words: Indonesia, journalists, censorship, Soeharto regime

\begin{abstract}
Abstrak
Di masa Soeharto, wartawan Indonesia terbagi menjadi dua bagian: yang kooperatif dan yang tidak kooperatif terhadap pemerintah. Tipe pertama adalah wartawan yang sangat mendukung pemerintah dan mau menyaring berita sensitif, sedangkan tipe kedua tidak hanya memberitakan informasi positif tapi juga negatif. Dalam penelitian ini, penulis menganalisis perjuangan wartawan independen atau non-kooperatif dalam melawan aturan sensorsip di Indonesia. Bagaimana mereka merespon dan cara apa yang dilakukan untuk menolak peraturan tersebut akan menjadi kunci pembasan dalam tulisan ini. Metode yang digunakan adalah metode sejarah, seperti heuristik, kritik, interpretasi dan historiografi. Hasil penelitian menunjukan bahwa wartawan independen ini membentuk aliansi jurnalis independen untuk mendapatkan kembali hak kebebasan berekspresi. Cara yang mereka gunakan adalah dengan menerbitkan buku, menggunakan internet, mengadakan seminar, dan mendirikan forum di kalangan mahasiswa. Usaha mereka, dengan dibantu krisis ekonomi, berhasil menumbangkan rezim otoriter.
\end{abstract}

Kata kunci: Indonesia, wartawan, sensorsip, rezim Soeharto

\section{INTRODUCTION}

In the history of Indonesian media, censorship is not a new case that has challenged Indonesian journalists. Since Dutch colonialism, the journalists have needed to filter news that is not considered sensitive by the government. That history, then, repeated in the Soeharto era (1967-1998) when the government considered that mass media, especially newspapers, could threaten the government as well as the national stability. As a result, the authoritarian government implemented some 
regulations to limit the freedom of speech, such as SIT (Surat Izin Terbit, publishing license), constitution bills to supervise the newspaper publishers' activities under the Ministry of Information, and a regulation to ban the newspapers and publishers that reported fake and sensitive issues.

It is interesting to note that in facing the government's attitude toward the sensitive news, Indonesian journalists are divided into two different ideologies and organisations: cooperative (associated with PWI, the Association of the Indonesian Journalists) and non-cooperative journalists (named the Alliance of Independent Journalists), but no recent pieces of literature specifically discussed that topic. Krishna Sen and David T. Hill's Media, Culture, and Politics in Indonesia (2000) shows how the regulation of censorship has affected Indonesian media industries. Some popular media that were directly under the government's control, such as newspapers, radio, and television hid all the social problems; while the other media, including books, music, and the internet were under regulation but not directly controlled, and were still circulating and used as social forum (Send dan Hill, 2000: 11-12). Sen and Hill's book covers all media during the New Order in Indonesia, but it neglects to discuss how books became alternative media for non-cooperative journalists to oppose the government's limitation on free speech.

Sen and Hill are not the only scholars who researched censorship in Indonesia. Many other writers are concerned with the topic and contribute to the study of Indonesia's media history. A specific discussion of self-censorship, for example, is available in Old Tricks in a New Era: Self-Censorship in Indonesian Journalism written by Ross Tapsell. Tapsell explains that journalists and students suffered from the limitation of speech when the New Order government banned their newspapers, so some resisted the government policy by publishing what was considered sensitive news (Tapsell, 2012: 230-31). While Tapsell illustrates the clash between the government and journalists, Toeti Kakiailatu focuses to examine the Indonesian newspapers as a forum for expressing criticism and the desire to change Indonesian politics. Here, Kakialatu explains how newspapers radically influenced Indonesian society to dispute the government's performance by conducting demonstrations and sharing opinions through newspapers (Kakialiatu, 2007: 60-71). Although both Tapsell and Kakialatu touch on the discussion about self-censorship and newspaper as a form of media, they miss explaining the differences between cooperate and noncooperative journalists and whether there are any alternative ways to express their journalism creativity other than newspaper.

Filling the gap in the recent studies above, I will discuss non-cooperative journalists' struggle against the New Order government while examining the government's political power to control both mass media and journalists through regulation and non-official attitude (e.g. suggestion of self-censorship and violence); and, how the non-cooperative journalists have attempted to find alternative media to disseminate news about the Indonesian problems. The different between my research and the other recent scholarship is that my research will show that non-cooperative journalists are different from other journalists who have cooperated with or been kept safe from the government's prohibition. Many researchers ignored those differences, so they made readers consider that the suffering journalists under the censorship and 
self-censorship regulations meant "the Indonesian journalists" in general. In fact, there were cooperative journalists who collaborated with the government to challenge those non-cooperative ones. These explanations will all be framed as an answer of the question, "To what extent did the Indonesian government suppress non-cooperative journalists during the New Order Indonesia?"

In short, there are three parts to the discussion in this paper. The first section will illustrate how the New Order government suppressed the Indonesian journalists in the "general meaning" (before being non- cooperative) through some regulations. It also will include the government's mild and violent ways to make the journalists cooperate as well as limitations of news that were considered "sensitive". In the second one, there will be a discussion of non-cooperative journalists' reaction to resisting authoritarianism, including demonstration, the establishment of the noncooperative journalist organisation named AJI (the Alliance of Independent Journalists), and their new tricks to publish sensitive news to avoid a ban. In the last one, it will show a debate as to whether the momentum of freedom of speech in the end of the regime, in 1998, was because of the merit of journalists to evoke the great demonstration in 1998, or because of the Asian economic collapse factor. The result of my study is that there are some limitations of the New Order's suppression of the Indonesian journalists in which the internal factors (the middle-class supported noncooperative journalists; the awareness of negative impact of censorship; and the eagerness of free speech) encouraged non-cooperative journalists to oppose the regulation and find another way to keep publishing news; and, external factors contributed to the authoritarians ending the limitation of free speech.

\section{RESEARCH METHOD}

In this research, I use historical methods, including collecting historical sources (heuristic), choosing the historical evidence based on its authenticity and credibility (criticism), interpreting and analysing the facts of history, and historiography. Most sources are the written and visual ones which I collected from several institutions, especially the National Library of Australia and the Australian National University libraries. The analysis of study, mostly, bases on the primary sources, such as several books, newspapers, and diaries written by historical actors (the journalists in the Soeharto era). The visual sources, like images, are also used to strengthen the research finding of how the Soeharto government supressed the non-cooperative journalists. It is interesting to note that during the data collection, some primary sources came after the 1980s written in the form of books. It shows that the journalists used this alternative to disseminate information when the government banned their newspapers. All this related sources are used to interpret the censorship case involved the authority and the journalists, like how the journalists coped with the ban and how the censorship regulation pushed them to look for another alternative medium to challenge the authoritarianism.

In narrating the discussion, the author uses the concept of challenge and response. Although Arnold Joseph Toynbee related this theory with a civilization, the Indonesian journalist struggle discussed in this essay firstly challenged by the government to release news, then responding the government decision, including using alternative media to criticize, getting separate from the Alliance of Indonesian 
Journalists (Persatuan Wartawan Indonesia, PWI), and gathering young people to do political discussions. Just like the description of Toynbee's challenge and response theory, the outside challenge leads the non-cooperative journalists to survive from the difficult condition.

\section{FINDING AND DISCUSSION}

\subsection{The Government's Tricks to Create Cooperative Journalists}

Within three decades of Soeharto's presidency, the Indonesian journalists were facing a dilemma because their freedom of speech, which was promised in the 1945 Constitution of the Republic Indonesia, was in question. In the first ten years of the New Order government, the government encouraged journalists to implement Pancasila press in which the content of newspapers should support the Indonesian ideology, so they needed to avoid publishing racial and religious conflicts (Arifin, 1992: 53-4). According to Ross Tapsell, to make journalists cooperate with the government, they promoted the concept of "developmental journalism" in which the journalists were a part of Indonesian society who fostered the national stability through the information they shared (Tapsell, 2012: 230-31). The concept of "Pancasila Press" become the reason why the New Order government passed several bills to limit the journalists' movement, including the prohibition of newspapers and magazines that would raise public riots and a regulation of having the license of publication (Kakialiatu, 2007: 62). These governmental ways to control journalists reflect how they were anxious about the function of newspapers as a powerful medium to spread information and influence people.

However, even though the Indonesian constitution had moved to implement Pancasila press, there were still some newspapers that published what was considered sensitive news about corruption. Surjomihardjo mentions that press regulation coloured the character of newspapers in 1968 when many newspaper headlines showed the information about a feature topic, such as travelling, but the presence of corruption in the middle pages raised a question of the regulation's effectiveness (Surjomihardjo, 1980: 236). Kakiailatu explains that the regulation was not effective because the information ministry staff adhered to a "telephone culture", privately suggesting by telephone that the newspaper editors filter their news (Kakialiatu, 2007: 65). This "telephone culture" was one of the informal tactics used to hide numerous scandals and problems under Soeharto's leadership.

As the informally suggested self-censorship succeeded in silencing the Indonesian journalists until 1971, many problems still emerged, either related to the authoritarian regime or the public. In the government, both corruption and nepotism flourished, with many officials' families monopolising the national project (Romano, 2003: 21). In the 1970s, for example, Soeharto's wife, Tien Soeharto, handled the TMII project (TMII, Beautiful Indonesian Miniature Park) which cost USD25 million (Seth, 1994: 2407). This project generated a lot of criticisim because President Soeharto preferred to implement his wife's project rather than improving infrastructure, especially in transport and roads. The country's social and economic problems arose because of the wide gap between the rich and the poor and the rise in poverty (Romano, 2003: 21). The economic problems before the late 1990s, however, are in 
question. Several economic and history scholars, including Amy L. Freedman and Thee Kian Wie, have argued about the economic improvement and the decline of poverty based on World Bank data during Soeharto presidency, especially before 1994 (Freedman, 2006: 85-6). However, this was contradicted in the 1970s when several newspapers, both local and international, recorded that demonstrations happened in 1974. In Indonesia, the Indonesia Raya daily newspaper progressively published some critiques from January $3^{\text {rd }}$ to $16^{\text {th }}$, 1974, against the Indonesian government for being dependent on foreign capitals, especially Japan. In the article titled "Welcome, Prime Minister Tanaka," for instance, the Indonesia Raya's editor claimed that the relationship between Indonesia and Japan is no more than because of the Japanese vested interest to exploit natural sources through their manifestation in Indonesia (Atmakusumah, 2008: 411-18). Two Australian newspapers, Tharunka and The Canberra Times, even reported in 1974 that some youth organisations planned to do demonstrations for several days, coinciding with the visit of Japanese Prime Minister Tanaka on 15 January 1974 (The Canberra Times, 1974: 4). The arrangement of those demonstrations was to protest the flourishing of foreign capital and companies in Indonesia, including Japanese's Toyota and Chinese manifestations (Tharunka, 1974: 4). The foreign newspapers' reports become evidence that international journalists watched what was happening in Indonesia when the journalists' activities were limited by their government.

However, President Soeharto never tolerated the intervention of journalists with his decision about the Indonesian economic policy. To avoid the non-cooperative journalists' influence in the bIndonesian government, seven newspapers that criticised the Indonesian relationship with Japan in January 1974 were banned, including Indonesia Raya, Pedoman, Kami, Jakarta Times, Abadi, Mingguan Mahasiswa Indonesia, and Express magazine. The ban caused several negative impacts on the journalists, such as having no revenue for several weeks and they were confused about which kinds were permitted and prohibited (Surjomihardjo, 1980: 248). Nevertheless, what surprising was that the government permitted those newspapers and magazines to publish news again after the prohibition of publishing for several weeks (Kakialiatu, 2007: 65-6). This government's attitude to the Indonesian journalists and their newspapers shows a unique character and raises a question: Were there any vested interests behind the government's decision? Why did they prohibit the journalists' activity for several weeks, but then allow the journalists to publish their newspapers again? What did they want from the journalists?

Looking at the Indonesian press constitution no. 11, 1966, that became a foundation of the Indonesian journalists and press activity, there are several articles that show ambiguity. In article 2 of the constitution, it states that the journalists need to publish news that does not contradict Pancasila, but articles 4 and 5 of the constitution explain that the press has the right to control and criticise the government; and, that the government cannot ban or implement censorship in newspapers (Indonesian Constitution, 1966). Article 2 could be interpreted freely by the government to justify their prohibition of some critical newspapers to keep the national stability (Heryanto at.al, 1994: xii). Meanwhile, the reason for the New Order's tendency to prohibit newspapers temporarily, but then allow them to be published again is possibly because of articles 4 and 5 above. At least until the new act passed in 1982 to replace the 1966 press regulation, there was no evidence that 
revealed that newspapers were banned permanently. This fact implicitly explains that the prohibition's aim was to make deterrent effects for the journalists, so they could intefere too much with the government.

Another justification that the New Order government's intention to make cooperative and muted journalists was the establishment of the only journalist association, called PWI (Persatuan Wartawan Indonesia, the Association of the Indonesian Journalists). The organisation aimed not only to monitor and network all Indonesian journalists, but also to obey the Minister of Information. Abdurrahman's statement in his work shows that PWI supported the government as it condemned some newspapers' critiques about the Japanese capital in 1974. The PWI leader who was also a journalist did not support some critical journalists, but issued a statement for all Indonesian journalists to avoid negative news that could cause riots (Dadang and Pakpahan, 1996: 79).

The PWI support for the government was because of two contradicting rationales: avoid conflict with the government to save their lives; and, get facility and position in the seat of government. The first reason is based on some pieces of evidence that explain that those who opposed the authorities could be in trouble. Hamzah in his Delik-Delik Pers Indonesia (Some Cases of the Indonesian Press) examines a case of a chief editor of the Sinar Pagi daily newspaper who published a corrupted act committed by a regent in Tangerang in 1982. Because of that report, the editor went to prison for six months (Hamzah, et.al, 1987: 97). Another case happened to a senior journalist, Mochtar Lubis, who criticised the relationship between Indonesia and PM Tanaka in 1974. Although the case had happened a year before, the Minister of Information sent him to Nirbaya Prison in Jakarta in 1975 for the allegation of defamation and causing the student demonstrations in January 1974 (Lubis, 2008: 2-3). His diary written during his detention for three months and ten days not only recorded his complaints about the New Order's attitude toward a rebellious journalist like him, but also became evidence to remind the generation that the New Order government was anti-criticism. Because of this first reason, all members of PWI preferred to obey rather than rebel. Secondly, different from the first reason, many non-cooperative journalists' works in the 1990s revealed that some PWI leading figures gained material support and a position in the political party. Togi E. Simanjuntak in Wartawan Independen (translated: Independent Journalists) explains that the orientation of the press since the President Soeharto era changed from "pers perjuangan" (press for struggle) to "industry press" in which most journalists choose to make money rather than struggle for their ideal of criticism and reaching the truth (Bujono and Hasibuan, 1995). Lubis, in his Nirbaya diary, also expresses the same statement that PWI had a "bad attitude, asked money to change facts, and asked for a facility" from the government (Lubis, 2008: 105). Those non-cooperative journalists' statements clearly explained that they never agree when the government intervenes the press.

The different ideologies between a few journalists and the PWI (consisting of majority of the Indonesian journalists) led to two different opposition groups in the Indonesian press world: the critical journalists known as non-cooperative journalists; and, the PWI, a group of cooperative journalists. From 1994 onward, the non- 
cooperative ones were too tired of a situation in which their rights to freely express their opinions as journalists in a democratic country was never defended.

\subsection{The Reaction of Non-Cooperative Journalists}

Never had the New Order of Indonesia experienced such long demonstrations until 1994 when the government banned three mainstream magazines, Tempo, DeTIK, and Editor. Ariel Haryanto states that the protests took place several times throughout Indonesia after 21 June 1994 with the intent to question and criticise the government moral's right to prohibit the publication of those magazines just because they reported B.J. Habibie, the Minister of Technology's plan to buy 39 second-hand war ships from East German (Heryanto at.al, 1994: 9). Another writer, Janet Steele, records that the bans could anger the middle-class and the public as they would no longer remain silent after 30 years of witnessing the Soeharto presidency (Steele, 2005: xiv). All strata of society, including journalists, students, artists, and the banned magazines' employees, marched to the Indonesian Press Council in Jakarta to meet the head of PWI to convey their grievances and the negative effects of the ban. A solution was not reached, and some activists were injured as anarchy broke out among police (Prasetyo, 1994). Nevertheless, these lengthy protests did not arouse the government to allow the freedom of expression; on the contrary, this historical event became the climax of the non-cooperative journalists' suffering as well as a milestone in their ongoing struggle against authoritarianism.

The relationship between non-cooperative journalists and the New Order government explained above caused mutually debilitating actions. The noncooperative journalists found several tricks to undertake their journalism activities and disseminate critical news. Firstly, they set up a counter-organisation against both PWI and the government called Aliansi Jurnalis Independen (AJI, the Alliance of Independent Journalists), which was founded on August 7th, 1994, a month after the bans (Dadang and Pakpahan, 1996: 45). A newspaper in 1996 that recorded an interview with ex-Tempo editor Goenawan Muhammad noted that Muhammad supported AJI by helping the group publish magazines and books (Casey, 1996).

It is important to explain that the government considered AJI and its magazine "illegal" because in the New Order government, every magazine and newspaper publisher needed to have a publishing or a marketing license. Without it, a journalist could not publish any news (Tapsell, 2012: 62-5). Its illegal status led AJI to undertake its programmes clandestinely, including publishing and circulating Independen magazine. However, AJI itself was established to oppose that license as the group believed that a marketing or publishing license was a tool misused by the government to control the national press (Dadang and Pakpahan, 1996: 45). AJI's opposition against those government policies is clearly stated in the Sirnagalih declaration, an attestation to founding AJI. The declaration, which was signed by more than 60 young and senior journalists, records how AJI opposed the censorship and the government intervention within the national press (Taufik, at.al, 2010: 6-7). Although AJI published its magazine without a marketing license, many subscribers from middleclass society were interested in buying Independen. The difference between the AJI magazine and other magazines is that it revealed the actual news about the 
Indonesian problems such as corruption, poverty, and the president's family's projects. The government never knew of the organisation and its activities until March 1995, when some police intelligence spied on it. Consequently, three of AJI's members were arrested, and the government did not permit AJI to continue its illegal activities (Dadang and Pakpahan, 1996: 87).

However, the closure of AJI's activities was not the end of non-cooperative journalists' struggle, as they looked for the second alternative to disseminate news and protests through other media: publishing books. Many books were released after the ban of AJI in 1995 to protest the New Order's arbitrariness, including Wartawan Independen (the Independent Journalists, 1995), Jurnalis Independen Diadili (Independent Journalists on Trial, 1996), and Reformasi Media Massa (The Reformation for Mass Media, 1998) (Sutrisno, 1998). In Wartawan Independen (1995), for instance, the AJI journalists wrote about when three of the AJI members were under arrest by the police (Bujono and Hasibuan, 1995). The aim of the book's publication was simple: the journalists wanted to disseminate news about what was happening to journalists in another form of media to society.

Using a book to record news and journalists' aspirations was an alternative way of spreading news, since spreading it through newspapers and magazines was considered impossible. Hill argued that the publication of a newspaper is different from a book in that it needs to periodically publish within a limited time; in contrast, a publisher can publish a book whenever it wants (Bujono and Hasibuan, 1995). Changing the media used to record an event from newspaper to book is also a clever idea because, during the New Order Indonesia, a book could be published without a license and could not be banned before its publication (Send dan Hill, 2000: 21-2). Therefore, a book could possibly circulate through society before the government and its spies track it.

The AJI's alternative way of using books is not new idea for Indonesian journalists. A few months after the case of three banned magazines in June 1994, some journalists in Yogyakarta, Indonesia, published Pers, Hukum, dan Kekuasaan (translated: "Press, Law, and Power," 1994) to support the struggle of non-cooperative journalists who bravely criticised mismanagement in the government body (Heryanto at.al, 1994: 9). Ex-Tempo's journalists also followed Yogyakarta's journalists' steps by releasing a book titled Mengapa Kami Menggugat ("Why We Sued," 1995) to complain about the government. The latter records the collection of ex-Tempo journalists' opinions about the government's decision to ban Tempo, which became a place for the journalists to devote their passion to journalism as well as a source for them to meet their economic needs for their livelihood (Bujono, 1995: 1920). As these two books circulated in society before AJI published its books, AJI journalists, some of whom were ex-Tempo journalists, gained inspiration and implemented the same way to hide from the government monitoring.'

\subsection{The Dawn of Freedom}

All Indonesian scholars believed that the fall of Soeharto regime on 21st May, 1998, marked the beginning of press freedom. This era, which is called Reformation, after May 1998 opened the gate for all national journalists in Indonesia to express their 
opinion, giving them the ability to critique the government. However, whether the freedom of the Indonesian journalists was primarily because of their struggle was still in debate. Many economists and social scholars argued that the Asian economic collapse at the end of 1997 is the main factor that led to the freedom of expression as well as the Reformation era while the other factors helped to succeed society's hope to end President Soeharto's power. Elizabeth Fuller Collins in her Indonesia Betrayed: How Development Fails states that when Indonesia faced the economic crisis in 1997, most of the middle-class society, including some parliament members, supported the pro-democratic reformation movement (represented by students and journalists) to end the old regime (Collins, 2007: 37). It is not surprising, then, that the great demonstrations happened between March and May 1998, and all the Indonesian media and journalists cooperated to disseminate news in the newspapers and on television. Amy L. Freedman believes that Soeharto could buy the nation's stability when the Indonesian economic situation reached a peak of prosperity during the 1970s and 1980s, a time when all Indonesian officials, the army, and the cooperative journalists gained their luxury from the government (Freedman, 2006: 85-6). The economic motive became one of their considerations for being on the President's side.

The economic factor clearly plays a role in the Indonesian public's inclination to obey the government prior to its fall in 1998. After 1997, many cooperative journalists changed their course to report controversial news about student demonstrations and national problems, which attracted people throughout Indonesia (Heryanto and Adi: 327). The journalists also revealed the issue of Chinese Indonesians as the trouble behind the economic crisis as many of them had become successful entrepreneurs in Indonesia. The repercussions of this issue had negative effects on all Chinese Indonesians, without exception, when protesters wrecked Chinese shops, and Chinese women were raped (Willnat and Aww, 2009: 120). The Indonesian military could not control the riots, and the chaotic situation also reflects that a majority of Indonesians believed that the New Order regime would not last long.

Regardless of the existence of some journalists who took an opportunity during the New Order instability, we need to recognise that there were the real noncooperative journalists who still used the principle of pers perjuangan ("press for struggle") until the dawn of Reformation in May 1998. Since the internet came to Indonesian public in the mid-1990s, many non-cooperative journalists set up a news website as a substitute for the banned magazine/newspapers (Casey, 1996). Joseph Saunders, for instance, mentions the role of AJInews as an online newspaper that reported the great demonstrations in May 1998 (Saunders, 1998: 45). The information about the existence of AJI reporters in the online world proved that the noncooperative journalists still struggled for the freedom of speech, even long before the economic condition in Indonesia got worse.

The Asian economic collapse that turned most Indonesian people to oppose President Soeharto, however, contributed to open the gate of freedom of speech in 1998. The financial crisis is a particular moment that led all Indonesian people, including all Indonesian journalists, to end the limitation of speech. Because of the merit of all Indonesian journalists and the existence of alternative media, such as books and the internet, the vast demonstration happened in May 1998 to ask President 
Soeharto withdraw from his position. Almost all Indonesian students from different regions came to Jakarta to take over Parliament House for five days in May 1998 (Sheng, 2009: 421). This role of students which was triggered by the provocation in mass media to oppose the government leads to many scholars to conclude that three factors gave a contribution to the freedom of the press, those are the economic crisis, student demonstrations, and the role of journalists with their mass media.

\section{CONCLUSION}

Democracy and freedom of expression are two words that should be side by side, but that did not apply in the New Order Indonesia (1967-1998) where the government controlled both journalists' activities and contents of newspapers through regulations. The government's policies led to two divided journalists: those who supported the government as they gained a sense of security and economic advantages, called the cooperative journalists; versus the opposition or noncooperative journalists. Even though the government found out several ways to suppress the non-cooperative ones, the journalists always looked for another alternative media after the ban, such as by publishing books and creating a forum and news website on the internet. These alternative media helped them to struggle for the freedom of speech and disseminate information in society, but they are one the only key factor in ending the New Order. The Asian economic crisis happened in late 1997 triggered the political instability but opened an opportunity for many people to conduct a great protest in May 1998 to insist President to end his tenure. The three factors: journalists and their alternative media, economic collapse, and big protests brought into the dawn of Reformation as well as freedom of expression. While many scholars have analysed both economic crisis and students protests in 1998 as the key reasons for the fall of Soeharto, the research about books as alternative media used by non-cooperative journalists for their struggle is never discussed. The topic can open up a new research in the future to question its effectivity to replace newspapers' position to disseminate news in society.

\section{REFERENCES}

Ahmad Taufik, at.al. 2010. Semangat Sirnagalih. Jakarta: Aliansi Jurnalis Independen. Abd. Rohim Ghazali (Ed.). 1998. Suara-suara Perih Masyarakat Indonesia. Bandung: Penerbit Mizan.

A. Hamzah, et.al. 1987. Delik-Delik Pers di Indonesia. Jakarta: Media Sarana Press.

Ariel Heryanto and Stanley Yoseph Adi, "The Industrialisation of Media in Democratising Indonesia," pp. 327-355.

Arifin, Anwar. 1992. Komunikasi Politik dan Pers Pancasila. Jakarta: Media Sejahtera.

Atmakusumah and Sri Rumiati Atmakusumah (Ed.). 2008. Tajuk-tajuk Mochtar Lubis di Harian Indonesia Raya. Jakarta: Yayasan Obor Indonesia.

Ayu Utami, at. al. 1994. Bredel 1994: Kumpulan Tulisan Tentang Pembredelan TEMPO, DETIK, EDITOR. Jakarta: Aliansi Jurnalis Independen. 
Bambang Bujono and Imran Hasibuan (Ed.). 1995. Wartawan Independen: Sebuah Pertanggungjawaban AJI. Jakarta: Aliansi Jurnalis Independen.

Bambang Bujono, et. al. (Ed.). 1995. "Mengapa Kami Menggugat". Jakarta: Yayasan Alumni Tempo.

Collins, Elizabeth Fuller. 2007. Indonesia Betrayed: How Development Fails. Honolulu: University of Hawai'I Press.

Committee to Protect Journalist. 1991. In the Censors' Shadow: Journalism in Soeharto's Indonesia. New York: Nov 1991.

Dadang RHs and Roy Pakpahan (Ed.). 1996. Jurnalis Independen Diadili: Pledoi Tiga Terpidana. Jakarta: Aliansi Jurnalis Independen,

Freedman, Amy L. 2006. Political Change and Consolidation: Democracy's Rocky Road in Thailand, Indonesia, Malaysia, and South Korea. New York: Palgrave McMillan.

Geoff Forrester and R.J. May (Ed.). 1998. The Fall of Soeharto. Bathurst: Crawford House Publishing.

Hill, David T. 1994. The Press in New Order Indonesia. Nedlands: University of Western Press.

Kakialiatu, Toeti. 'Media in Indonesia: Forum for Political Change and Critical Assessment,' Asia Pacific Viewpoint, Vol. 48, No. 1, April 2007, pp. 62-5.

Krishna Sen and David T. Hill. 2000. Media, Culture, and Politics in Indonesia. Victoria: Oxford University Press.

Lane, Max. 2008. Unfinished Nation: Indonesia before and after Soeharto. London and New York: Verso.

Lars Willnat and Annette Aw (Eds.). (2009). Political Communication in Asia. New York: Routledge.

Lubis, Mochtar. 2008. Nirbaya: Catatan Harian Mochtar Lubis dalam Penjara Orde Baru. Jakarta: Yayasan Obor Indonesia.

Lubis, Mochtar. 1992. Budaya, Masyarakat, dan Manusia Indonesia. Jakarta: Yayasan Obor Indonesia.

Saunders, Joseph. 1998. Academic Freedom in Indonesia: Dismantling Soeharto Era Barriers. New York: Human Right Watch.

Ramadhan K. H. (Ed.). 1995. Mochtar Lubis: Bicara Lurus Menjawab Pertanyaan Wartawan. Jakarta: Yayasan Obor Indonesia.

Romano, Angela. 2003. Politics and the Press in Indonesia. London and New York: Routledge Curzon.

Seth, S.P. 'Clamp Down on Press in Indonesia.' Economic and Political Weekly, vol. 29, no. 37 (Sep. 10, 1994), p. 2407.

Steele, Janet. 2005. Wars Within. Jakarta: Equinox Publishing Indonesia.

Surjomihardjo, Abdurrachman. 1980. Beberapa Segi Perkembangan Sejarah Pers di Indonesia. Jakarta: Departemen Penerangan and LIPI. 
Sheng, Andrew. 2009. From Asian to Global Financial Crisis. New York: Cambridge University Press.

Sutrisno, Eri (Ed.). 1998. Reformasi Media Massa. Jakarta: Aliansi Jurnalis Independen.

Indonesian constitution, "Principles for Press," no. 11 1966, articles 2, 4, 5.

\section{Newspaper}

"Indonesia: the 1974 Riots," Tharunka (Kensington, NSW, 1953-2010), Wednesday 27 March 1974, p. 4.

“Large Protests Expected," the Canberra Times (ACT: 1926-1995), Monday 7 January 1974, p. 4. 